\title{
ORIGINAL ARTICLE \\ Seasonal emergence counts from a multispecies horseshoe bat (Chiroptera: Rhinolophidae) roost in the Philippines
}

\author{
Frex D. Dimaculangan ${ }^{1}$, Angela Como Jacobson ${ }^{2}$, Phillip Alviola ${ }^{1,3}$, James Alvarez ${ }^{1,3}$, Jodi L. Sedlock ${ }^{2, *}$
}

\author{
${ }^{1}$ University of the Philippines, Los Baños, \\ Institute of Biological Sciences, Los \\ Baños, Philippines. \\ ${ }^{2}$ Lawrence University, Biology \\ Department, Appleton, Wisconsin 54911 \\ USA. \\ ${ }^{3}$ University of the Philippines-Los Baños \\ Museum of Natural History, Los Baños, \\ Philippines. \\ *Corresponding author: \\ sedlockj@lawrence.edu \\ DOI: https://doi.org/10.14709/ \\ BarbJ.12.1.2019.06 \\ Keywords: caves, Chiroptera, maternity \\ colony, Rhinolophus, Southeast Asia, \\ tropical forest

\begin{abstract}
The seasonal roost use of Philippine horseshoe bats (Family: Rhinolophidae) is poorly known. Here, we monitored an undisturbed rock crevice roost comprised of four Rhinolophus species on Mount Makiling, Philippines, to document seasonal changes in colony size and species composition. Evening emergences were videotaped using an IR spotlight and an IR-sensitive camera and were acoustically recorded using an ultrasonic detector. Emergence counts ranged from an average of 7,965 bats in the wet season to 177 bats in the dry season. Higher emergence counts in the wet season, and the presence of post-lactating females and juveniles, together indicated that Rhinolophus arcuatus and Rhinolophus inops used the rock crevice as a maternity roost. Rhinolophus macrotis and Rhinolophus virgo were detected during all survey months but comprised a smaller proportion of the wet-season emergence than $R$. arcuatus and $R$. inops. These data, while limited in scope, provide the first evidence of seasonal cave use by Philippine horseshoe bats and highlight the potential conservation value of this particular roost as a maternity site for horseshoe bats within the Makiling Forest Reserve.
\end{abstract}

\section{INTRODUCTION}

One of the main threats to bats is the loss of suitable diurnal roosts (Mickleburgh et al. 2002). This is especially true in Southeast Asia, where species occupying permanent cave roosts are declining as a result of mineral and guano extraction, hunting, unregulated tourism and incidental disturbance (Kingston 2010, Furey \& Racey 2015). Often, changes in cave colony size are due to human disturbance (Cardiff et al. 2009, Sedlock et al. 2014, Furey \& Racey 2015); however, population fluctuations may occur in response to season (Nuñez-Novas et al. 2016), social organization (Trajano 1996), or reproductive status (Kunz 1982, Furey et al. 2011). Therefore, documenting natural monthly variation in colony size in the absence of disturbance may inform conservation and management of cave-dwelling bat species by identifying critical periods of occupancy and avoiding monitoring efforts when bats are absent.

Horseshoe bats (Rhinolophidae) are widespread in Southeast Asia (Simmons 2005), and many utilize caves (Csorba et al. 2003, Furey et al. 2016). Horseshoe bats in Southeast Asia are seasonally monoeostrus (Furey et al. 2011, Nurul-Ain et al 2017), and give birth to one pup during the early onset of the rainy season. Therefore, it is likely that colony size varies seasonally. In the Philippines, there are at least ten horseshoe bat species (Heaney et al. 2010), and intensive cave surveys have documented them occupying caves during various times of the year (Mould 2012, Warguez et al. 2013, Sedlock et al. 2014, Alviola et al. 2015, Tanalgo \& Tabora 2015, Phelps et al. 2016). However, no published studies have monitored individual caves to explicitly assess seasonal fluctuations in colony size (Tanalgo \& Hughes 2018). The objective of this study was to document monthly changes in the number and species composition of emergent bats at an undisturbed rock crevice roost within Mount Makiling Forest Reserve, Philippines.

\section{MATERIALS AND METHODS}

\section{Study Site}

This study took place at a cave roost formed from large volcanic rocks within the Makiling Forest Reserve (MFR), an ASEAN Heritage Park, on Luzon Island, Philippines $\left(14^{\circ} 8^{\prime} \mathrm{N}\right.$, $\left.121^{\circ} 12^{\prime} \mathrm{E}\right)$. The climate is characterized by a distinct, although very variable, wet (May-December) and dry (January-April) seasons (Pancho 1983). The mean daily temperature range of the MFR is $25-29.6^{\circ} \mathrm{C}$, and annual rainfall averages 1645 $2299 \mathrm{~mm}$ (measurements taken at 21 meters above sea level, Combalicer \& Im 2012, Fig. 1).

The study roost, formed of volcanic rock, had a northeastern facing orientation on the side of the mountain at approximately $600 \mathrm{~m}$ elevation in second-growth midmontane forest (Fig. 2). The four known openings utilized 
by bats (entrances 1-4) were on the side of a steep rock wall, about $100 \mathrm{~m}$ north of the main hiking trail leading to the peak (Sedlock 2002). All four entrances were small $(<$ $1 \mathrm{~m}$ in diameter), quite high on a rocky wall, and therefore inaccessible to humans.

\section{Acoustic monitoring}

To document species composition and relative abundance, we acoustically recorded the entire emergence with an ultrasonic detector placed below the most centrally located and heavily utilized entrance (entrance 1). During the wet seasons, we used an Anabat SD2 detector (Titley Scientific) during one night (2015), and a full spectrum SM4BAT (Wildlife Acoustics, Maynard, MA; sampling rate = $256 \mathrm{kHz}$ ) on a second night (2016). On all dry season sampling nights (17), we used an Ultramic Ultrasonic USB microphone (Dodotronic). The Ultramic was connected to a laptop running Sound Emission Analyzer (SEA) Wave software (G. Pavan and Centro Interdisciplinare di Bioacustica e Ricerche Ambientali, University of Pavia 2011; sampling rate $=250$ $\mathrm{kHz}$ ). We identified calls to species level with a call library compiled from bats we captured exiting the roost. In order to estimate relative species abundance from the stream of bats exiting the roost, we calculated the proportion of each minute (divided into 12 five-second intervals) that a species' call was detected during the emergence. For example, if a species' call was detected in 6 of 12 -second intervals, the proportion for that minute would be 0.5 . We then graphed the proportion presence for each species over time. Detectability can be influenced by recording equipment (Adams et al. 2012); however, the proximity of the microphones to the entrances $(<5 \mathrm{~m})$ enhanced the detectability of emergent bats' calls and should minimize equipment bias.

\section{Bat capture and reference recordings}

We captured bats emerging from the roost to assess sex and reproductive status and to record reference calls. We set mist nets $10-20 \mathrm{~m}$ away from the entrances for three net-hours (one net-hour = one $6 \times 2.6 \mathrm{~m}$ net open for one hour) during the wet season, and 27 net-hours during the dry season on nights when we were not videotaping or acoustically recording the emergence. The recorded species were sexed, aged, and identified using Ingle \& Heaney (1992). Reproductive status, forearm length, and weight of captured bats was also measured prior to release. Reference calls were recorded from bats in hand approximately 30 $\mathrm{cm}$ from the microphone using either an UltraSoundgate ultrasonic recorder (Avisoft Bioacoustics; sampling rate $=256 \mathrm{kHz}$ ) or an Ultramic Ultrasonic USB microphone (Dodotronic) (sampling rate $=250 \mathrm{kHz}$ ) and saved directly to a computer. Peak frequency (i.e. frequency with the most energy) of one high quality call from each individual was determined from the power spectrum using Avisoft SASLabPro software (version 5.2.12, Avisoft Bioacoustics). Capture and handling of animals followed all relevant Philippine rules and regulations, recommendations by the American Society of Mammologists (Sikes et al. 2011), and were approved by the Lawrence University animal care and use committee.

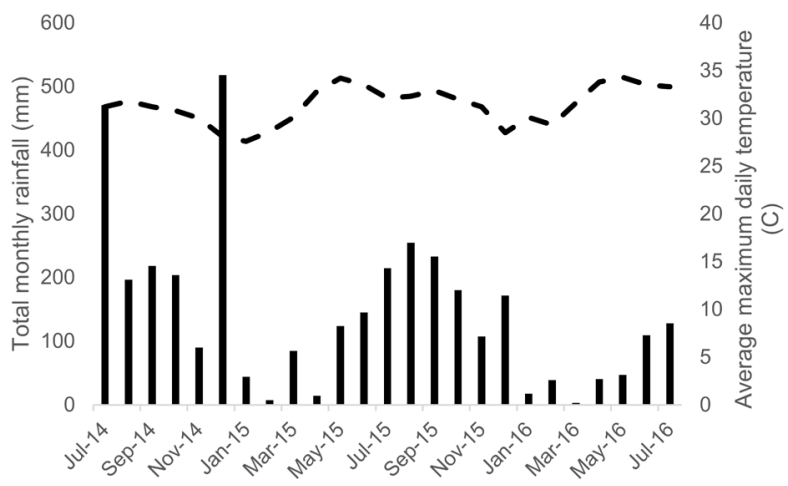

Fig. 1 - Average monthly rainfall (bars) and temperature (dashed line) measured at the International Rice Research Institute at the base Mount Makiling. Data were acquired from the IRRI Climate Unit (https://sites.google.com/a/irri.org/climate-unit/resources).

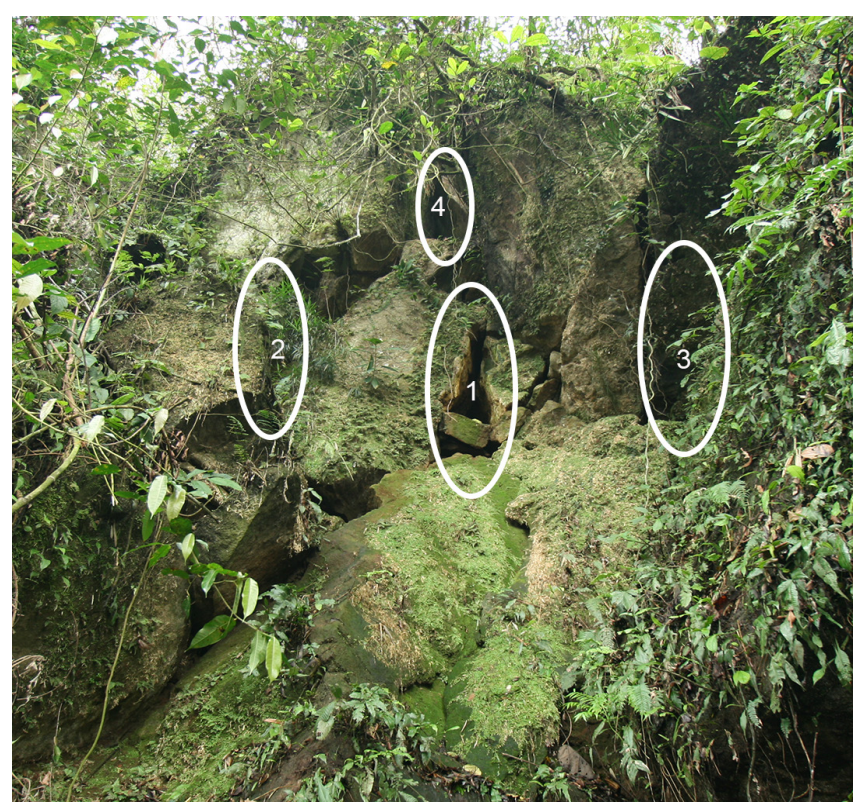

Fig. 2 - Study roost site indicating the location of entrances 1-4.

\section{Emergence counts}

We monitored bat emergence for a total of 20 nightsthree nights during the wet season (2nd August 2014, 1st August 2015, and 30th July 2016), and 17 nights during the 2016 dry season (December 26-30th, 2015; January 13-17th, 2016; February 7-10th, 2016; and March 11-12nd and 14th, 2016). December is a transition month usually classified as wet season; however, because the sampling dates are towards the end of the month when rainfall was low (average rainfall Dec. 20-31 $=1.2 \mathrm{~mm}$ ) we will refer to the December-March sampling as "dry season." Our observations during all sampled nights began before sunset (ca. $1730 \mathrm{~h}$ ) and ended after all bats had emerged.

During all nights, we videotaped the emergence of bats using IR lights and an IR sensitive camera. On the three wet season nights, we used a SONY Nightshot video camera and an infrared spotlight (Sony Electronics, San Diego, CA) trained on entrance 1. During all other nights, we used a SONY OU12BV Color Closed Circuit Television (CCTV) Camera with a built-in infrared light (Sony Electronics, San Diego, CA) positioned to frame all four entrances. We played back the 

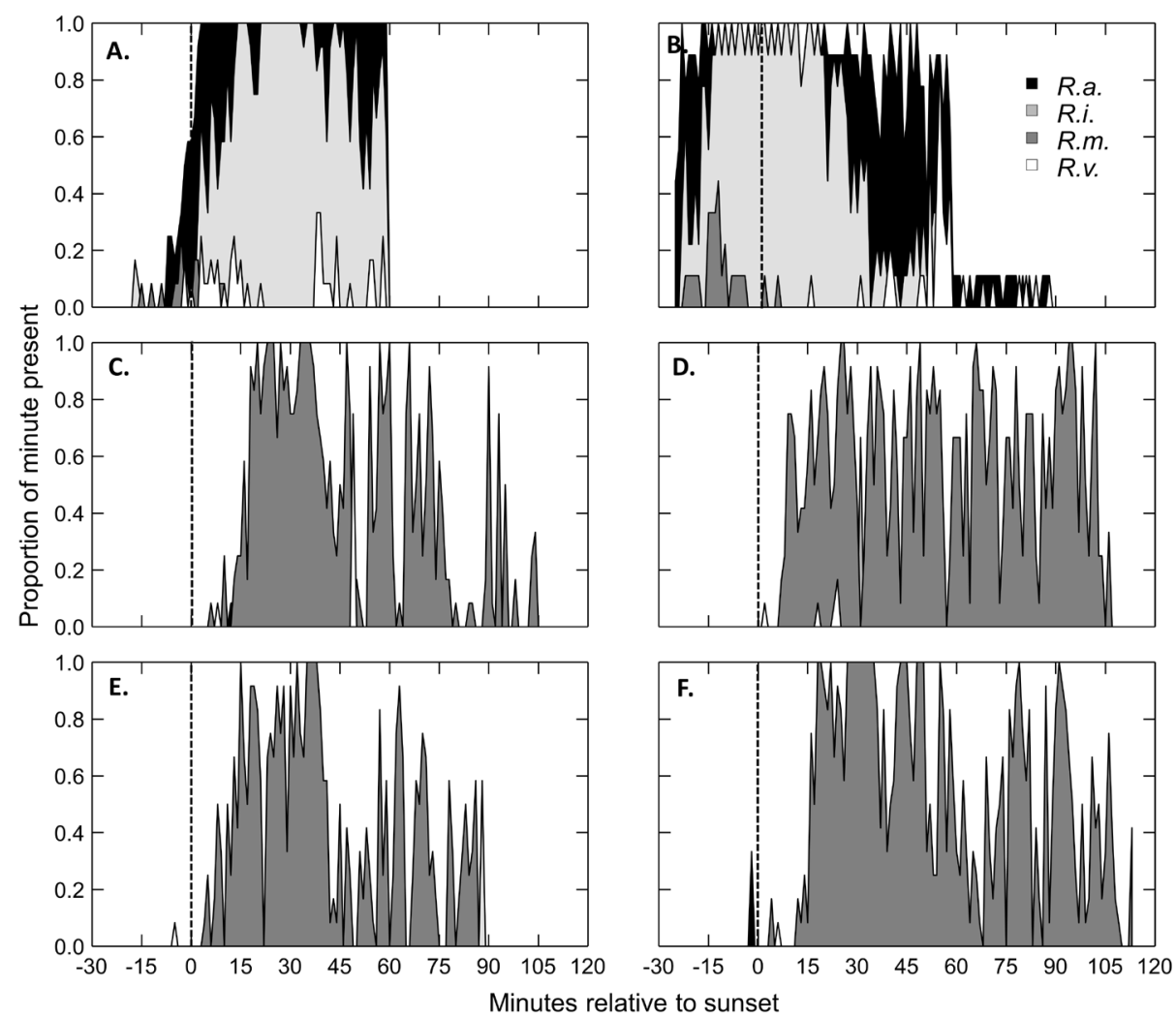

Fig. 3 - Relative abundance of R. arcuatus (R.a.), R. inops (R.i.), R. macrotis (R.m.), and R. virgo (R.v.) expressed as the proportion of each minute a species' call was detected in (A) August 2015, (B) July 2016, (C) December 2015, (D) January 2016, (E) February 2016, and (F) March 2016. The Dec-March graphs represent the sampling date with the highest total emergence for that month. The dashed vertical line indicates sunset.

video in slow motion and manually counted each emergent bat. We stopped counting when exits were less than one bat per minute and re-entries were more than one per minute.

\section{Statistical Analysis}

We used a Mann-Whitney $U$ test to determine whether emergence counts from entrance 1 during the dry and wet seasons differed. We took the average count for each month during the dry season and compared those averages to the three counts taken over three years in the wet season. We used Kruskal-Wallis tests to assess monthly differences in emergence counts by entrance during the dry season, and Dunn's test for multiple comparisons with Bonferroni correction for post hoc monthly comparisons (PMCMR package, Pohlert 2014). Statistical analyses were run in $R$ (R Development Core Team 2018). We used an alpha reject value of 0.05 .

\section{RESULTS}

\section{Acoustic monitoring}

Rhinolophus arcuatus, $R$. inops, R. macrotis, and $R$. virgo were detected acoustically; however, the relative proportion of recording time in which each was detected differed between the wet (Fig. 3A \& B) and dry season (Fig. 3C \& $F)$. $R$. arcuatus and $R$. inops were detected throughout the emergence and dominated most recording minutes in the wet season (Fig. 3A \& $\mathrm{B}$ ), whereas $R$. macrotis calls was more abundant during the dry season. Additionally, the relative proportion of the emergence in which $R$. macrotis was detected was higher during dry season emergence than in the wet season.

\section{Bat capture and reference calls}

We captured 68 individuals comprised of four species $-R$. arcuatus, $R$. inops, $R$. macrotis, and $R$. virgo (Table 1$)$. $R$. arcuatus is a common, medium-sized (forearm length = 40-48 $\mathrm{mm}$ ) bat, that represents a species complex in the Philippines consisting of different morphotypes that vary in size and noseleaf morphology (Heaney et al. 2010, Heaney et al. 2016). Those we captured had a "narrow" rather than a "wide" noseleaf sella (see Sedlock \& Weyandt 2009). $R$. inops and $R$. virgo are both widespread Philippine endemics but differ in size (forearm length $=49-57 \mathrm{~mm}$ versus $37-44$ $\mathrm{mm}$, respectively). $R$. macrotis is similar in size to $R$. arcuatus, (forearm length $=43-47 \mathrm{~mm}$, Heaney et al. 2010), but has proportionately larger ears. Parous females and juveniles of all species except $R$. macrotis (Table 1 ) were captured during the wet season. However, captures during the dry season only included $R$. arcuatus, $R$. macrotis, and $R$. virgo. Mean peak frequencies of echolocation calls for each species are given in Table 1.

\section{Emergence counts}

Emergence counts in entrance 1 during the wet season were significantly higher than during the dry season $\left(\chi^{2}=4.5\right.$, $P=0.034$; Fig. 4). During the dry season, the number of bats emerging from entrance 1 also differed among months $\left(\chi^{2}=\right.$ 


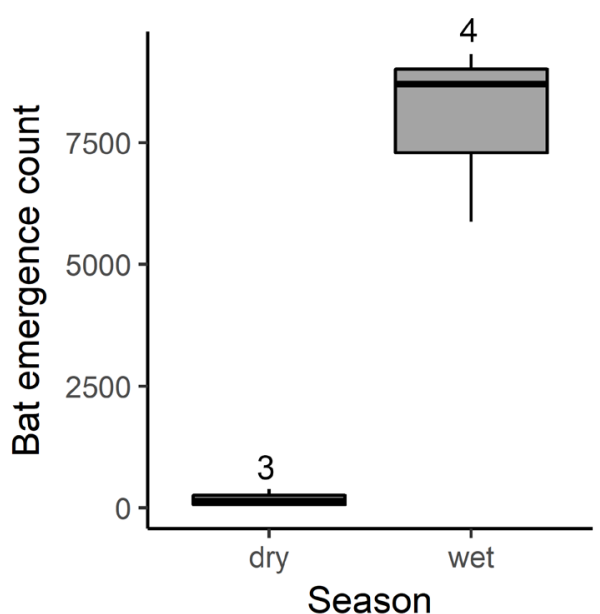

Fig. 4 - Box plot of dry and wet season emergence counts from entrance 1. Sample sizes are given above boxes.
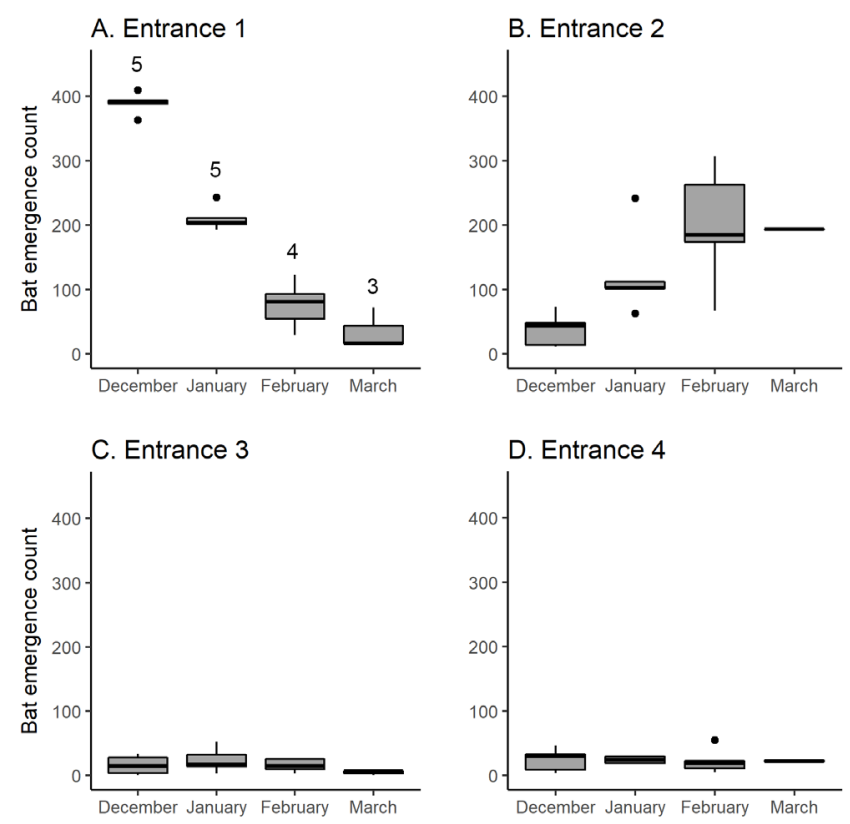

Fig. 5 - Monthly differences in emergence counts by entrance during the dry season. Sample sizes for each month are given above boxes in panel $\mathrm{A}$ and are the same for all entrances.

Table 1 - Number of bats captured exiting roost by season and species. Capture rate (number captured/net-hours) given in parentheses. Abbreviations: $\mathrm{F}=$ female adult, $\mathrm{PF}=$ parous female, $\mathrm{M}=$ male adult, $\mathrm{J}=$ juvenile. Peak $=$ average peak frequency \pm standard deviation (sample size).

\begin{tabular}{|c|c|c|c|c|c|c|c|c|c|}
\hline \multirow{2}{*}{ Species } & \multicolumn{4}{|c|}{ Wet season } & \multicolumn{4}{|c|}{ Dry season } & \multirow{2}{*}{ Peak (kHz) } \\
\hline & $\mathbf{F}$ & PF & M & J & $\mathbf{F}$ & PF & M & J & \\
\hline R. arcuatus & $6(2.00)$ & $13(4.3)$ & & $13(4.33)$ & & & $1(0.03)$ & & $71.9 \pm 1.5(16)$ \\
\hline R. inops & & $1(0.33)$ & & $11(3.66)$ & & & & & $54.3 \pm 1.3(9)$ \\
\hline R. macrotis & & & & & $1(0.03)$ & & $6(0.22)$ & $5(0.19)$ & $50.9 \pm 1.1(12)$ \\
\hline R. virgo & & $2(0.67)$ & & $3(1.00)$ & $2(0.07)$ & & $3(0.11)$ & $1(0.03)$ & $85.5 \pm 0.5(3)$ \\
\hline
\end{tabular}

15.407, $P=0.001$, d.f. $=3$; Fig. 5A). Specifically, the average emergence count in December was significantly higher than in February $(P=0.012)$ and March $(P=0.003)$. The average emergence count from entrance 2 also differed among months $\left(\chi^{2}=11.201, P=0.010\right.$, d.f. = 3; Fig. 5B); however, December counts were significantly lower than in February $(P=0.046)$ and March $(P=0.017)$. Average emergence counts did not differ among months from entrance $3\left(\chi^{2}=\right.$ 3.186, $P=0.364$, d.f. $=3$; Fig. $5 C)$ or entrance $4\left(\chi^{2}=0.572, P\right.$ $=0.903$, d.f. $=3$; Fig. 5D).

\section{DISCUSSION}

Emergence counts and acoustic data revealed a decline in the number of emergent bats from entrance 1 between the wet and dry seasons by as much as $95 \%$ and a change in species composition. One explanation is that the two most commonly recorded species in the wet season (i.e. $R$. arcuatus and $R$. inops) may use the rock crevice as a maternity roost but may disperse to alternative roosts after the pups are weaned. Seasonal, temporary use of maternity roosts is common among temperate bat species (Kunz 1982), but has not been reported in tropical horseshoe bats. However, Furey et al. (2011) did report an increase in horseshoe bat captures at caves in northern Vietnam during the wet season, suggesting seasonal cave use. Moreover, similar to our study, most lactating females were captured during the wet season (Furey et al. 2011). We acknowledge that the drop in colony size from the wet to the dry season may also be an anomaly, given that we only monitored emergence during one dry season. Moreover, the number of emergent bats can vary with weather and insect availability (Erkert 1982). It is unlikely that our low dry season exit counts were the result of bats remaining inside the roost during good weather on all 17 nights of dry season sampling. Finally, the use of different recording equipment during the dry and wet seasons could have potentially biased our results. Specifically, the higher quality camera used in the dry season could have resulted in higher exit counts than in the wet season. However, despite this potential bias, we counted far more bats exiting the roost in the wet season.

Unlike $R$. arcuatus and $R$. inops, $R$. macrotis utilized our study cave year around, and appeared to increase in number during the dry season. It is possible that $R$. macrotis individuals moved into the roost when the other species dispersed after weaning young. These data support the claim that $R$. macrotis is a cave-obligate species in 
the Philippines (Sedlock 2002, Heaney et al. 2010, 2016). Additionally, entrance 1 counts decreased and entrance 2 counts increased over the four dry season months. One explanation may be that these entrances open into two separate caves, and the same individuals changed roosts. $R$. virgo was present during the wet and dry season but in relatively low numbers. $R$. virgo is often found in small groups in caves (Alviola et al. 2015) and culverts (Sedlock 2002), therefore, our data support the idea that $R$. virgo does not form large aggregations (Heaney et al. 2016).

Given the limited scope of this study, we encourage further cave monitoring research to determine how consistent and widespread seasonal cave use is among Philippine horseshoe bats. If subsequent studies find that natural fluctuations in colony size are common, cavemonitoring protocols could emphasize passive monitoring during the wet season when the maximum number of species and individuals are utilizing caves. Additionally, while the absence of bats is often indicative of human disturbance, there may be some cases where absences are due to natural fluctuations in colony size.

\section{ACKNOWLEDGEMENTS}

We are grateful to those who assisted us in the field, including M. Dixon, W. Reyes, A. Rice, F. Dimaculangan, J. Llamas and R. Llamas. The Makiling Center for Mountain Ecosystems, the University of the Philippines Los Baños, and the Region IV-A Philippine Department of the Environment and Natural Resources granted us permission to conduct this research. Conversations during Southeast Asian Bat Conservation and Research Unit workshops (SEABCRU; USA National Science Foundation, Grant No. 1051363) inspired this research. Lawrence University Excellence in Science Fund and the University of the Philippines Los Baños Museum of Natural History funded the fieldwork. Suggestions from two anonymous reviewers improved the quality of this paper.

\section{REFERENCES}

ADAMS, A. M., JANTZEN, M. K., HAMILTON, R. M. \& FENTON, M. B. (2012). Do you hear what I hear? Implications of detector selection for acoustic monitoring of bats. Methods in Ecology and Evolution, 3(6): 992-998. https://doi.org/10.1111/j.2041-210X.2012.00244.x

ALVIOLA, P. A., MACASAET, J. P. A., AFUANG, L. E., COSICO, E. A. \& ERES, E. G. (2015). Cave-dwelling bats of Marinduque Island, Philippines. Museum Publications in Natural History, 4: 1-17.

CARDIFF, S. G., RATRIMOMANARIVO, F. H., REMBERT, G. \& GOODMAN, S. M. (2009). Hunting, disturbance and roost persistence of bats in caves at Ankarana, northern Madagascar. African Journal of Ecology, 47(4): 640-649. https://doi.org/10.1111/j.1365-2028.2008.01015.x

COMBALICER, A. \& IM, S. (2012). Change anomalies of hydrologic responses to climate variability and land-use changes in the Mt. Makiling Forest Reserve. Journal of Environmental Science and Management, 15 (SUPPL.1): 1-13.
CSORBA, G., UJHELYI, P. \& THOMAS, N. (2003). Horseshoe bats of the world (Chiroptera: Rhinolophidae). Alana Books, Bishop's Castle, United Kingdom. xxxii + 160 pp.

ERKERT, H. G. (1982). Ecological aspects of bat activity rhythms. In: Ecology of Bats. Plenum, New York, USA. 201-242 pp.

FUREY, N., MACKIE, I. J. \& RACEY, P. A. (2011). Reproductive phenology of bat assemblages in Vietnamese karst and its conservation implications. Acta Chiropterologica, 13(2): 341-354. https://doi.org/10.3161/150811011X624811

FUREY, N. \& RACEY, P. A. (2015). Conservation ecology of cave bats. In: Bats in the anthropocene: Conservation of bats in a changing world. Springer, Cham. 463-500 pp. http://doi.org/10.1007/978-3-319-25220-9

FUREY, N., WHITTEN, T., CAPPELLE, J. \& RACEY, P. (2016). The conservation status of Cambodian cave bats. In: International speleological project to Cambodia 2016 (provinces of Stoeng Treng, Kampong Speu, Banteay Meanchey and Battambang). Speleo Club Berlin, Berlin, Germany. 82-95 pp.

HEANEY, L. R., BALETE, D. S. \& RICKART, E. A. (2016). The mammals of Luzon Island: biogeography and natural history of a Philippine fauna. Johns Hopkins University Press, Baltimore, Maryland, USA. xi + 287 pp.

HEANEY, L. R., DOLAR, M. L., BALETE, D. S., ESSELSTYN, J. A., RICKART, E. A. \& SEDLOCK, J. L. (2010). Synopsis of Philippine mammals. Field Museum of Natural History.

INGLE, N. R. \& HEANEY, L. R. (1992). A key to the bats of the Philippine Islands. Fieldiana: Zoology, new series, 69: 1-44. https://doi.org/10.5962/bhl.title.3504

KINGSTON, T. (2010). Research priorities for bat conservation in Southeast Asia: a consensus approach. Biodiversity and Conservation, 19(2): 471-484. https:// doi.org/10.1007/s10531-008-9458-5

KUNZ, T. H. (1982). Roosting ecology of bats. In: Ecology of bats. Plenum Press, New York, USA. 1-55 pp.

MICKLEBURGH, S. P., HUTSON, A. M. \& RACEY, P. (2002). A review of the global conservation status of bats. Oryx, 36(1): 18-34. https://doi.org/10.1017/ S0030605302000054

MOULD, A. (2012). Cave bats of the central west coast and southern section of the northwest Panay peninsula, Panay Island, the Philippines. Journal of Threatened Taxa, 4(11): 2993-3028. https://doi.org/10.11609/JoTT. 03104.2993-3028

NUÑEZ-NOVAS, M. S., LEON, Y. M., MATEO, J. \& DAVALOS, L. M. (2016). Records of the cave-dwelling bats (mammalia: Chiroptera) of Hispaniola with an examination of seasonal variation in diversity. Acta Chiropterologica, 18(1): 269-278. https://doi.org/10.316 1/15081109ACC2016.18.1.016 
NURUL-AIN, E., ROSLI, H. \& KINGSTON, T. (2017). Resource availability and roosting ecology shape reproductive phenology of rain forest insectivorous bats. Biotropica, 49(3): 382-394. https://doi.org/10.1111/btp.12430

PANCHO, J. V. (1983). Vascular flora of Mount Makiling and vicinity (Luzon, Philippines). Kalikasan, The Philippine Journal of Biology, supplement no. 1: 1-476 pp.

PHELPS, K., JOSE, R., LABONITE, M. \& KINGSTON, T. (2016). Correlates of cave-roosting bat diversity as an effective tool to identify priority caves. Biological Conservation, 201: 201-209. https://doi.org/10.1016/j. biocon.2016.06.023

POHLERT, T. (2014). The Pairwise Multiple Comparison of Mean Ranks Package (PMCMR). R package, https:// CRAN.R-project.org/package=PMCMR

R DEVELOPER CORE TEAM. (2018). R: a language and environment for statistal computing. R Foundation for Statistical Computing, Vienna, Austria.

SEDLOCK, J. L. (2002). Autecology and the conservation of insectivrous bats on Mt. Makiling, philippines. Silliman Journal, 42: 163-201.

SEDLOCK, J. L., JOSE, R. P., VOGT, J. M., PAGUNTALAN, L. J. \& CARIÑO, A. B. (2014). A survey of bats in a karst landscape in the central Philippines. Acta Chiropterologica, 16(1): 197-211. https://doi.org/10.3161/150811014X683390

SEDLOCK, J. L. \& WEYANDT, S. E. (2009). Genetic divergence between morphologically and acoustically cryptic bats: novel niche partitioning or recent contact? Journal of Zoology, 279(4): 388-395. https://doi.org/10.1111/ j.1469-7998.2009.00634.x
SIKES, R. S., GANNON, W. L. \& AMERICAN SOCIETY OF MAMMALOGISTS. (2011). Guidelines of the American Society of Mammalogists for the use of wild mammals in research. Journal of Mammalogy, 92(1): 235-253. https://doi.org/10.1644/10-MAMM-F-355.1

SIMMONS, N. B. (2005). Order Chiroptera. In: Mammal species of the world: a taxonomic and geographic reference. Johns Hopkins University Press, Baltimore, Maryland, USA, 312-529 pp.

TANALGO, K. C. \& HUGHES, A. C. (2018). Bats of the Philippine Islands - A review of research directions and relevance to national-level priorities and targets. Mammalian Biology, 91: 46-56. https://doi. org/10.1016/j.mambio.2018.03.005

TANALGO, K. C. \& TABORA, J. A. G. (2015). Cave-dwelling bats (Mammalia: Chiroptera) and conservation concerns in south central Mindanao, Philippines. Journal of Threatened Taxa, 7(15): 8185-8194. https://doi. org/10.11609/jott.1757.7.15.8185-8194

TRAJANO, E. (1996). Movements of cave bats in southeastern Brazil, with emphasis on the population ecology of the common vampire bat, Desmodus rotundus (Chiroptera). Biotropica, 28(1): 121-129. https://doi. org/10.2307/2388777

WARGUEZ, D., TAGARDA, P. M. M., \& DEMAYO, C. G. (2013). Diurnal roosting preferences of cave-dwelling bats in Northeastern Agusan Del Norte, Mindanao, Philippines. Extreme Life, Biospeleology \& Astrobiology, 5(2): 103-116. 